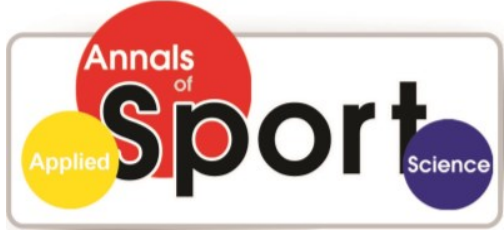

www.aassjournal.com

ISSN (Online): $2322-4479$

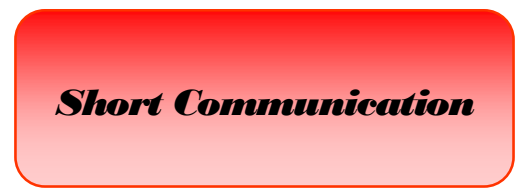

Received: $19 / 02 / 2014$

Accepted: 30/09/2014

\title{
Effects of Reasoning Ability on Field Goal Shooting Skills of Female Basketball Players
}

\section{${ }^{1}$ Virendra Kumar Singh, ${ }^{2}$ C. D. Agashe*}

1. Sports Officer, Shri Shankaracharya Mahavidyalaya, Junwani, Bhilai, India.

2. HOD, SOS in Physical Education, Pt. Ravishankar Shukla University, Raipur, India.

\begin{abstract}
In the present study, field goal shooting skills of female basketball players were assessed in the background to their reasoning ability. The sample consists of 100 female intercollegiate basketball players (age $=21.05 \pm 1.67$ yrs.). Shooting skills and reasoning ability were assessed by Johnson's "Basketball Field Goal Speed Shooting Test" and Mixed Type Group Test of Intelligence prepared by Mehrotra (1984), respectively. Results reveal that field goal shooting ability of female basketball players exhibiting superior reasoning ability was found to be significantly better as compared to field goal shooting ability of female basketball players with low and average reasoning ability. It was concluded that shooting skills of female basketball players is influenced by their cognitive ability i.e. ability to rationalize problems in proper sequence.
\end{abstract}

Key Words: Shooting, Cognitive, Basketball players, Reasoning Ability.

Corresponding Author:

C. D. Agashe

E-mail: cagash@yahoo.com 


\section{INTRODUCTION}

Reasoning is an ability which helps a person come to some definitive answers from any given situation or information. It is sometimes termed as the speed of information processing. The Speed at which any given information is processed helps a person quickly draw conclusion from any given information. Logically, an inference is called deductive if the truth of the initial information (or premises) guarantees the truth of the conclusion. The inference is called inductive if the truth of the premises makes the conclusion probable but not certain. Many researchers have found that performances on deductive and inductive tests are strongly related. Hence reasoning ability is to draw logical conclusions from any given situation.

The importance of cognitive ability in sports setting has long been an area of interest for researchers as Vernon and Mori (1992), Kioumourtzoglou et al. (1998), Planinsec and Pisot (2006), Karalejić and Jakovljević (2008), Kamkary, Akbari, and Shokrzadeh (2012) have established the relationship between motor performance and cognitive ability i.e. intelligence (1-5).

Like any sport, basketball requires mastery of complex motor skills in order to perform basic fundamental skills i.e. throwing, passing, dribbling, and shooting. The basic fundamental skills in basketball require a player to quickly assess the situation and act accordingly. Since it is a fast-paced sport, the time to process information in the court is very little. This is when the importance of speed of information processing or reasoning ability may have a vital role. Although researchers studied various facets of basketball (6-11), so far no such study has been conducted in order to study shooting skills of basketball players in the light of their reasoning ability, hence the present study is an attempt to assess shooting skills of female basketball players on the basis of their level of reasoning ability they possess. It was hypothesized that shooting skills of female basketball players would be significantly influenced by their reasoning ability.

\section{MATERIALS AND METHODS}

Participants. In the present study, 100 female intercollegiate basketball players (age $=21.05 \pm 1.67$ years) were selected as sample. The selection of subjects was done from intercollegiate tournaments held in the State of Chhattisgarh, India. The selection of sample was based on convenience sampling technique.

Tools. To assess shooting skills of selected female basketball players, Johnson Basketball Field Goal Speed Shooting Test was used. This test is highly reliable and valid. The direction of scoring for this test is "The higher the score is, the better the ability is".

Mehrotra's (1984) Mixed Type Group Test of Intelligence (MGTI) was used to assess reasoning ability of selected subjects (12). It has two parts i.e. the verbal and nonverbal intelligence test. Both parts have 50 statements. The test-retest reliability of the verbal test is 0.89 , while it is 0.82 for nonverbal test. The full test reliability coefficient is 0.86 . The validity verbal test is .86 , and it is 0.72 for non-verbal test, while the overall validity of the test is 0.87 when it was correlated with teacher's ratings. Only non-verbal intelligence part which assesses reasoning ability was used in the present investigation.

Procedure. Johnson basketball Field Goal Speed Shooting Test was administered to selected female basketball players under the supervision of investigators. The reasoning ability part of MGTI test was administered to each selected female basketball player in a peaceful corner. The response pertaining to MGTI was scored off per author's manual. Scores on Johnson basketball Field Goal Speed Shooting Test was also recorded for each selected subject. 
To divide cases into categories of superior, average and inferior reasoning ability, quartile (Q1 and Q3) statistical technique was used. Subjects whose reasoning ability scale lies below Q1 (14.25) were assigned to inferior reasoning ability, while subjects whose scores lies above Q3 (23.00) were assigned to superior reasoning ability category, and scores on reasoning ability test lying between Q1 (14.25) and Q3 (23.00) were assigned to average reasoning ability category.

Statistical Analysis. All results are expressed as mean (Standard Deviation). To find out the effects of reasoning ability on shooting skills of selected female basketball players, 'One Way ANOVA' was used. The analysis was performed by Statistical Package for Social Sciences (SPSS) and Statistical significance level was set at the 0.05 .

\section{RESULTS}

Descriptive Statistics (Mean \pm S.D) of shooting skills of female basketball players on the basis of their reasoning ability summarised in the table 1 .

Table 1. Shooting Skills of Female Basketball Players on The Basis of Their Reasoning Ability

\begin{tabular}{|c|c|c|c|}
\hline Goal Shooting Skills & N & Mean & S.D \\
\hline Superior & 29 & 12.03 & 1.84 \\
\hline Inferior & 25 & 7.40 & 2.53 \\
\hline Average & 46 & 8.65 & 3.82 \\
\hline
\end{tabular}

The findings in table 2 clearly suggest that field goal shooting ability of female basketball players did differ significantly on the basis of their reasoning ability $(\mathrm{F}=$ $17.44, \mathrm{p}=0.01)$.

Table 2. Comparison of Shooting Skills on The Basis of Their Reasoning Ability

\begin{tabular}{cccccc}
\hline Source & df & Sum of Squares & Square Means & F & Sig. \\
\hline Between Groups & 2 & 326.320 & 163.180 & & \\
Within Groups & 97 & 907.400 & 9.355 & 13.895 & $0.01^{* *}$ \\
Total & 99 & 1233.760 & & & \\
\hline$* *: \mathrm{p}<0.01$. & &
\end{tabular}

On the basis of LSD post hoc test (graph 1), female basketball players with superior reasoning ability showed significantly better field goal shooting skills as compared to female basketball players with average (Mean Difference $=3.38, \mathrm{p}<0.05$ ) and inferior (Mean Difference $=4.63, \mathrm{p}<0.05$ ) level of reasoning ability. But the field goal shooting skills of female basketball players with average was not found to be different from inferior reasoning ability statistically (Mean Difference $=1.25, \mathrm{p}>0.05$ ).

\section{DISCUSSION and CONCLUSION}

Precise movements are required for field goal speed shooting in basketball. Naturally and for precise movements, psycho-motor abilities are of great importance. It has also been proved that information, processing speed and working memory are important aspects of psycho-motor abilities (13). To 
realize the cognitive and effective domains of motor behavior, psychomotor aspects work as a medium. All these domains are interlinked and affect each other. When a sportsperson is performing a basic skill, the body and mind must work harmoniously. The results of the present study give positive indications that reasoning ability influences shooting skills of basketball players. The greatest and most statistically significant correlations with the factor of general intelligence are obtained in motor variables whose structure is characterized by predominant coordination, balance, speed of alternative movements, and explosive strength, rather than in motor tasks consisting of unusual movement structures, where maximum speed is required along with the correct performance of the task.
Other motor abilities do not have statistically significant relationships with intelligence (14). Since field goal speed shooting requires certain degree of motor coordination in basketball, there is no surprise that basketball players with superior reasoning ability excelled in field goal speed shooting as compared to players with inferior reasoning ability. In the same lines, Cashmore (2010) and Voss et al. (2010) also observed similar results $(15,16)$. Hence speed of information processing or in other words reasoning ability is a potential enough variable to influence basic fundamental skills in basketball i.e. field goal shooting skills.

It was concluded that reasoning ability is an important marker that influences shooting skills of female basketball players.

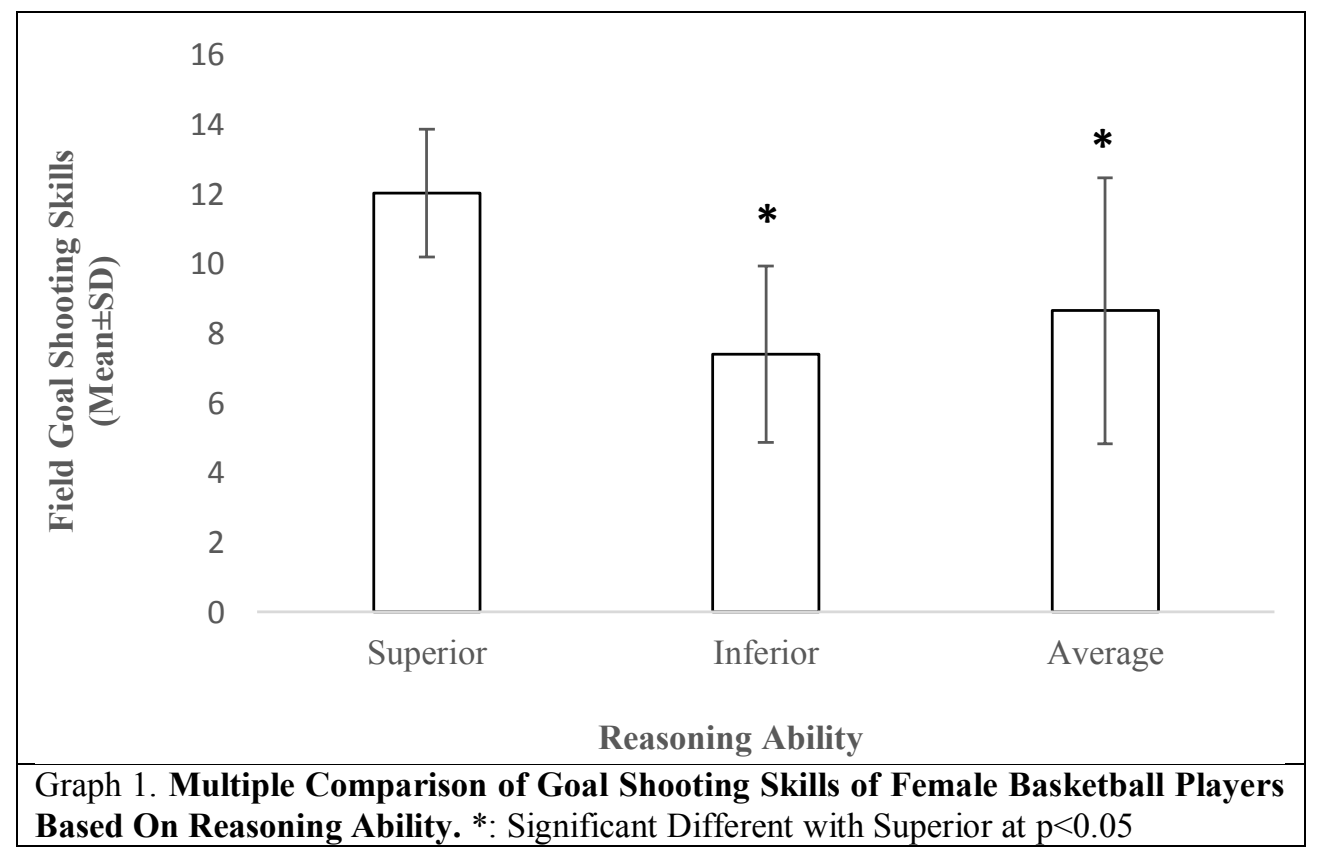

\section{REFFRENCES}

1. Kamkary K, Akbari P, Shokrzadeh S. Effects of Personality Profiles and Profiles of IQ on Elite Athletes' Volleyball's Performance. European Journal of Experimental Biology. 2012;2(6):2352-9

2. Karalejić M, Jakovljević S. Cognitive abilities of young basketball players and their actual success. Fizička kultura. 2008;62(1-2):109-23.

3. Kioumourtzoglou E, Derri V, Tzetzls G, Theodorakis Y. Cognitive, perceptual, and motor abilities in skilled basketball performance. Perceptual and motor skills. 1998;86(3):771-86.

4. Planinsec J, Pisot R. Motor coordination and intelligence level in adolescents. Adolescence. 2006;41(164):66776. 
5. Vernon PA, Mori M. Intelligence, reaction times, and peripheral nerve conduction velocity. Intelligence. 1992;16(3-4):273-88.

6. Balciunas M, Stonkus S, Abrantes C, Sampaio J. Long term effects of different training modalities on power, speed, skill and anaerobic capacity in young male basketball players. Journal of sports science \& medicine. 2006;5(1):163-70.

7. Patee T, Frewen M, Beer J. Association of eye color and sex with basketball free throws by elementary school children. Percept Mot Skills. 1991;73(3 Pt 2):1181-2.

8. Pates J, Maynar I, Westbury T. An Investigation into the Effects of Hypnosis on Basketball Performance. Journal of Applied Sport Psychology. 2001;13(1):84-102.

9. Poczwardowski A, Fisher M, editors. The impact of mental preparation on free throw shooting and self-efficacy with collegiate basketball players: A psychological skills training approach. European Federation of Sport Psychology Congress; 2001; Copenhagen, Denmark.

10. Sillero Quintana M, Refoyo Roman I, Lorenzo Calvo A, Sampedro Molinuevo J. Perceptual visual skills in young highly skilled basketball players. Percept Mot Skills. 2007;104(2):547-61.

11. Watanabe T, Sato T, Igawa S. Accuracy of Skill Performance in the Basketball Free Throw Shooting. BIO Web of Conferences. 2011;1:00096.

12. Mehrotra PN. Manual for mixed type of group test of intelligence (Verbal and non-verbal). Agra: Agra National Psychological Corporation; 1984.

13. Miller LT, Vernon PA. The general factor in short-term memory, intelligence, and reaction time. Intelligence. 1992;16(1):5-29.

14. Popoviæ B. Specificity of anthropological status in girls of younger school age under the influence of programmed exercising of developmental gymnastics 2010 [Thesis In Serbian].

15. Cashmore E. Making Sense of Sports: Routledge; 2010.

16. Voss MW, Kramer AF, Basak C, Prakash RS, Roberts B. Are expert athletes 'expert' in the cognitive laboratory? A meta-analytic review of cognition and sport expertise. Applied Cognitive Psychology. 2010;24(6):812-26. 


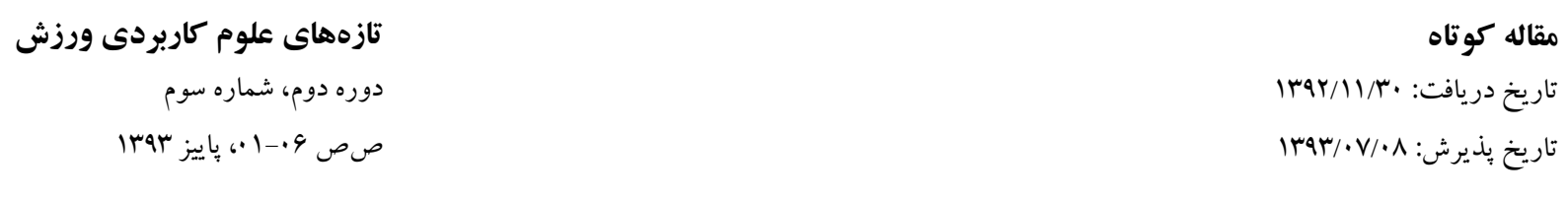

\section{اثر توانايى استدلال بر مهارتهاى ميدانى شوت كَل دختران بسكتباليست}

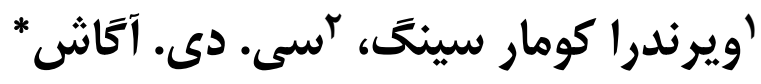

$$
\text { ז. I. مسئول ورزش، شرى شانكاراجاريا ماهاويديالايا، جونوانى، باهيلاى، هندوستان. }
$$

جكيده

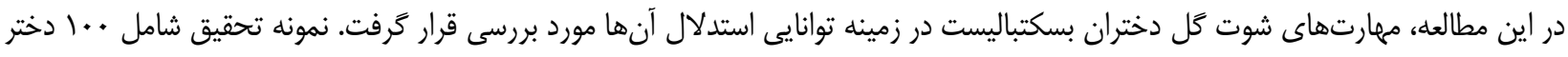

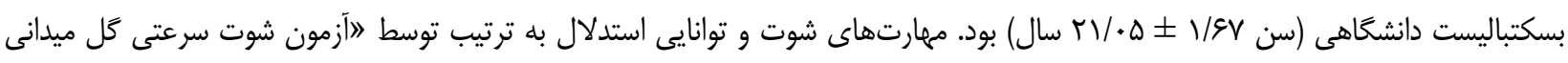

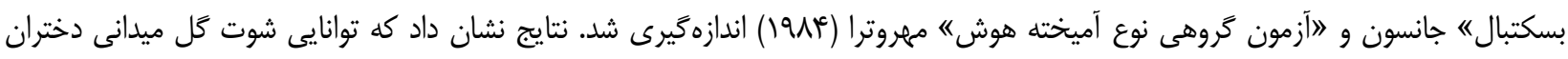

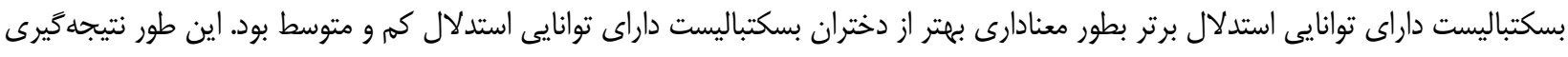

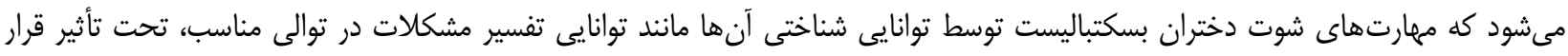

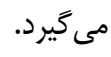
وازَّان كليدى: شوت، شناختى، بسكتباليست، توانايى استدلال. 